\title{
Traditional Uses of Miombo Woodland Tree Species in Sikonge District, Tanzania
}

\author{
Fadhili Hamza Mgumia*, Juvenal Nkonoki, John Safari \\ Institute of Rural Development Planning, Dodoma, Tanzania \\ Email address: \\ fmgumia@yahoo.com (F. H. Mgumia),fmgumia@irdp.ac.tz (F. H. Mgumia) \\ ${ }^{*}$ Corresponding author
}

\section{To cite this article:}

Fadhili Hamza Mgumia, Juvenal Nkonoki, John Safari. Traditional Uses of Miombo Woodland Tree Species in Sikonge District, Tanzania. International Journal of Natural Resource Ecology and Management. Vol. 2, No. 4, 2017, pp. 69-78. doi: 10.11648/j.ijnrem.20170204.11

Received: April 11, 2017; Accepted: April 28, 2017; Published: June 27, 2017

\begin{abstract}
Traditional use of Miombo woodland plants was investigated in Ugunda Forest Reserve in Sikonge District, Tanzania. Collaborative Field Work and Focus Group Discussions were used to generate information on uses of Miombo woodlands. Findings showed that local communities derived various goods and services from Miombo woodlands. Out of 106 plants recorded, 74species were found to provide multiple uses to the local communities. These species provided 18 forest products/services. The major categories of uses were food plants $(62.2 \%)$, handcraft plants $(56.8 \%)$, domestic plants $(47.3 \%)$. Further, results revealed that the Miombo woodlands provided $72.2 \%$ of Non- Timber Forest Products (NTFPs) compared with $27.8 \%$ of Timber Forest Products (TFPs). This study has demonstrated that impact of utilization decrease with increase of distance from the settlement suggesting high dependence of forest resources by local communities surrounding Ugunda Forest Reserve. However, conversion of Miombo woodlands to short-duration crop lands and harvesting woods for curing tobacco and charcoal making are the major threats to the woodland resources. Efforts are needed to promote best practices of forest management that will ensure sustainable supply of forest products and services. Promoting practices that enhance judicious use of NTFPs, which is known to be less destructive to forest ecosystem, would particularly result into long term benefits on both NTFPs and TFPs.
\end{abstract}

Keywords: Miombo, Plant Uses, Ethno-botany, Tanzania

\section{Introduction}

Miombo woodlands are the most extensive tropical woodlands in Africa, covering almost 2.4-2.7 million $\mathrm{km}^{2}$ [1, 2 , 3]. These woodlands are typically found in Central, Southern and Eastern Africa. The term Miombo describes woodlands dominated by the genera Brachystegia, Julbernadia and or Isoberlinia, which are the three closely related genera from the legume family of Fabaceae, subfamily Caesalpinioidae [4]. The term is derived from a local name "Muuyombo" of the Nyamwezi tribal group in Tabora, Tanzania which refers to a tree Brachystegia boehmii [5]. The term Muuyombo is used both in Tanzania and Zambia.

Extensive coverage of Miombo, makes them important to the livelihood systems of millions of rural and urban dwellers in Central and Eastern Africa [2, 6, 7]. These plants provide several goods and services including fuelwood, building materials, traditional medicines, food and ecosystem services
$[2,6,8]$. Hence, the Miombo are used for livelihood and as safety nets especially during hunger [7, 9]. There are, however, records of high level of deforestation and forest degradation of the Miombo woodlands due to utilization for which attention is required $[3,10]$.

In Tanzania, Miombo woodlands are the dominant vegetation type covering about $95 \%$ of the total forest area [11]. Livelihoods of a significant number of people depend on forests and woodlands through the supply of various products/services including fuelwood, construction materials, traditional medicines, food, fodder and carbon storage [12, 13]. In addition, the Miombo woodlands are central to spiritual functions in local communities. Various reports show that communities with such functions conserve specified trees and even blocks of Miombo woodlands [14, $15,16]$

In spite of its importance to livelihoods, studies on the roles of Miombo woodlands in Tanzania are limited. Those that have documented the use of Miombo woodlands 
resources [e.g. 7, 17, 18] have offered limited analysis to species level and the relationship between utilization and woodland resource abundance [19]. Besides, there may be variations in plant uses due to differences in culture and social-economic settings across locations. In particular, such information is lacking from Miombo woodlands of Sikonge district which cover almost $50 \%$ of Tabora region and $11 \%$ of the Miombo area of Tanzania [20]. Empirical data on the role of Miombo woodlands in supporting livelihoods would be useful in creating awareness on the need for sustainable management and conservation of Miombo woodlands. The objectives of this study were to (i) assess the role of Miombo woodland resources to the livelihood of local communities taking into account specific uses of tree species and (ii) establish the abundance and availability of useful trees and shrubs in Miombo area along the gradient of use.

\section{Methodology}

\subsection{Study Area}

Sikonge district $\left(5^{\circ} 15^{\prime}\right.$ and $6^{\circ} 45^{\prime}$ Sand $31^{\circ}$ and $\left.34^{\circ} \mathrm{E}\right)$ is one of seven districts in Tabora region, western of Tanzania. The district covers a total area of $21,000 \mathrm{~km}^{2}$ (NLUPC, 1999) that accounts for about $29 \%$ of total area of the Tabora region. The general vegetation of the study area is dominated by the Miombo woodlands. The Nyamwezi, Sukuma and the Tutsi make up the main ethnic composition. The district has 43 villages. Of these, two villages namely Mitwigu and Igalula were selected for the study. These villages were selected because they share a common border with Ugunda Forest Reserve. In such locations, it could be possible to obtain rich information on uses of forest products. The main economic activities in the villages are agriculture and livestock keeping. Major crops grown are maize, cassava and groundnuts as food crops, while tobacco as cash crop. Timber and honey harvesting are also practiced. At the time of study, Mitwigu and Igalula villages had 3000 and 1850 inhabitants, respectively.

\subsection{Data Collection}

To collect information on uses of tree and shrub species, an ethno-botanical survey was conducted in each of the two selected villages. Collaborative Field Work (CFW) and Focus Group Discussions (FGDs) were employed in data collection. These methods are considered to be the most suitable for ethno-botany survey [21]. In each village, one group of four elders participated in the study. Selected individuals were those who had rich knowledge of plants and their uses. Before commencing the study, the participants of the study were given a brief explanation about the objective of the study and the approach to data collection. The approach involved establishing transect in each village. One transect was established in each village, running from the border to the inside of Ugunda Forest Reserve (Thereafter referred to as Inside Forest Reserve (IFR)), from the forest border towards the villages (Forest in Transition Zone (FTZ)) and near the settlement towards Forest Reserve (Forest Near Settlement (FNS)).

Plots measuring $25 \times 25 \mathrm{~m}$ were laid at an interval of 200 $\mathrm{m}$. Plots of this measure are considered adequate for floristic studies in Miombo woodlands [22]. Overall, ten plots were established within IFR, ten at the FTZ and five from settlement boarder of each village towards the forest reserve(FNS). Thus, a total of 50 plots (equivalent to $6.25 \mathrm{ha}$ ) were established. Within each plot, names of plants and their uses were identified and documented in local names. The identification of species was restricted to trees and shrubs only. In addition, diameter at breast height $(\mathrm{DbH})$ was measured for all trees with diameter greater than $3 \mathrm{~cm}$ and height of three (small, medium and bigger) trees in each plot.

FGDs involved 10 resource persons (five males and five females) who were engaged in each village. The discussions were held in local language and Kiswahili; detailing uses of plants and the general importance of Miombo woodlands to livelihoods. The resource persons were prompted to ensure that uses were not overlooked. At the same time participants were encouraged to admit if they did not know a tree species or its use(s). The information gained was used to supplement data collected from ethno-botanical survey. Translation of the identified species from local names to botanical names was made with the use of a master checklist of tree and shrub species detailed in [23].

\subsection{Data Analysis}

The collected data on individual plant species were analysed to gain understanding of its use(s) relative to all possible uses of tree species obtained during CFW and FGDs. A formula modified from Martin [24] was used to determine the relative importance of a tree species to local people as the number of direct use(s) for a particular tree species/total number of possible uses of tree species $\mathrm{x} 100$. Uses that were related (e.g. fruits, medicines) referred to as secondary categories were grouped under one general category e.g. food plants. Other general categories were handcraft plants, domestic plants, spiritual plants, and miscellaneous uses. Data were then analysed for descriptive statistics mainly frequencies and percentages. Analysis was also carried out in terms of whether use(s) could be termed as Non-Timber Forest Products (NTFPs) or Timber Forest Products (TFPs). The qualitative data obtained from observation and FGDs were transcribed and analyzed using qualitative content analysis technique.

For forestry inventory data, wood/biomass parameter including stem $\mathrm{ha}^{-1}$, basal area $\mathrm{ha}^{-1}$ and volume ha ${ }^{-1}$ were computed using the formula and procedures developed by Philips [25]. The parameters were calculated for plants in each plot and then expressed in hectares. Tree volume was calculated as $\mathrm{Vi}=0.0001 * \mathrm{di}^{2.032} * \mathrm{hi}^{0.66}[26]$, whereby $\mathrm{Vi}=$ the volume of a tree $i ; \mathrm{di}=$ the diameter for a tree $i$ and hi $=$ the height of the three $i$. In addition, Shannon-Wiener Diversity Index was calculated as H' $=$ Sum (-pi* $\log ^{\text {a }}$ (pi) [27] whereby $\mathrm{H}^{\prime}$ = Shannon-Wiener Diversity Index; pi = proportion of individuals of species $i$ in the sample; $\log _{\mathrm{a}}=$ natural 
logarithm.

\section{Results and Discussion}

\subsection{Uses of Miombo Woodland Resources}

Table 1and Appendix 1 present results on uses of various trees and shrubs found in the Miombo woodland. In the 50 plots surveyed, a total of 106 trees and shrubs species were recorded. Out of 106 trees and shrubs species recorded, 77 species $(73 \%)$ were found useful to the local people. Most of them had multiple uses. However, three plants could not be identified, and were therefore, dropped out from further quantitative analysis. The 74 identified useful plants belonged to 59 genera and 27 families. The dominant families were Caesalpinioideae followed by Combretaceae and Euphorbiaceae (Figure 1). Further, participants of the study identified 18 uses (forest products and services) of Miombo plants.

The uses fall into five general categories namely food plants, handcraft, domestic plants, spiritual plants and other uses. The most dominant category of use was food, followed by handcraft plants and domestic plants. Most of the uses derived from the Miombo woodlands were fuelwood, traditional medicines, poles and edible fruits. Findings of this study provide further evidence of the significant support to livelihoods the Miombo woodlands have as reported elsewhere [28, 29, 30]. In Urumwa- Tanzania, for example, Njana et al. (2013) reported a total of 82 species provided 16 forest products while Bruschi et al. (2014) reported 98 species providing 178 uses in Mozambique.

Generally, NTFPs were derived more (72.2\%) from Miombo compared to TFPs (27.8\%) (Table 1 and Appendix 1). Studies have shown that NTFPs may contribute to biodiversity conservation [31, 32], and therefore, promoting them may increase the value of forest products to local communities. Such an arrangement may lead to a win-win strategy where both conservation of ecosystems and improvement of community welfare are achieved [33].

Table 1. Summary of forest products (uses), number of species and type of forest use.

\begin{tabular}{|c|c|c|c|}
\hline Category of forest products & Number of species & $\%$ of species & Type of forest use \\
\hline \multicolumn{4}{|l|}{ Food plants } \\
\hline Traditional medicines & 32 & 43.2 & $\mathrm{~N}$ \\
\hline Fruits & 20 & 27.0 & $\mathrm{~N}$ \\
\hline Total & 46 & 62.2 & \\
\hline \multicolumn{4}{|l|}{ Handcraft Plants } \\
\hline Poles & 22 & 29.7 & $\mathrm{~T}$ \\
\hline Wood utensils & 9 & 12.2 & $\mathrm{~T}$ \\
\hline Timber & 8 & 10.8 & $\mathrm{~T}$ \\
\hline Ropes & 8 & 10.8 & $\mathrm{~N}$ \\
\hline Small poles & 7 & 9.5 & $\mathrm{~N}$ \\
\hline Handles & 6 & 8.1 & $\mathrm{~T}$ \\
\hline Traditional beehives & 5 & 6.8 & $\mathrm{~N}$ \\
\hline Traditional storage structure & 2 & 2.7 & $\mathrm{~N}$ \\
\hline Carvings & 1 & 1.4 & $\mathrm{~T}$ \\
\hline Total & 42 & 56.8 & \\
\hline \multicolumn{4}{|l|}{ Domestic Plants } \\
\hline Fuel wood & 32 & 43.2 & $\mathrm{~N}$ \\
\hline Fences & 2 & 2.7 & $\mathrm{~N}$ \\
\hline Gum & 1 & 4.1 & $\mathrm{~N}$ \\
\hline Total & 35 & 47.3 & \\
\hline \multicolumn{4}{|l|}{ Spiritual Plants } \\
\hline Worshipping & 5 & 6.8 & $\mathrm{~N}$ \\
\hline Traditional protection & 4 & 5.4 & $\mathrm{~N}$ \\
\hline Total & 9 & 12.2 & \\
\hline \multicolumn{4}{|l|}{ Miscellaneous uses } \\
\hline Browse/fodder & 9 & 12.2 & $\mathrm{~N}$ \\
\hline Poison & 1 & 1.4 & $\mathrm{~N}$ \\
\hline Total & 10 & 13.5 & \\
\hline Total number of useful species & & & 74 \\
\hline Total number forest products (uses) & & & 18 \\
\hline
\end{tabular}

$\mathrm{T}=\mathrm{TFPs}=$ Timber Forest Products $\mathrm{N}=$ NTFPs $=$ Non Timber Forest Products

However, NTFPs exploitation does not necessarily lead to forest conservation [19, 34, 35], as some utilization of NTFPs such as fuelwood collection involve destructive harvesting that result in forest degradation and deforestation [36]. In this case, therefore, it is important that utilization practices be regulated for sustainability of Miombo woodlands. 


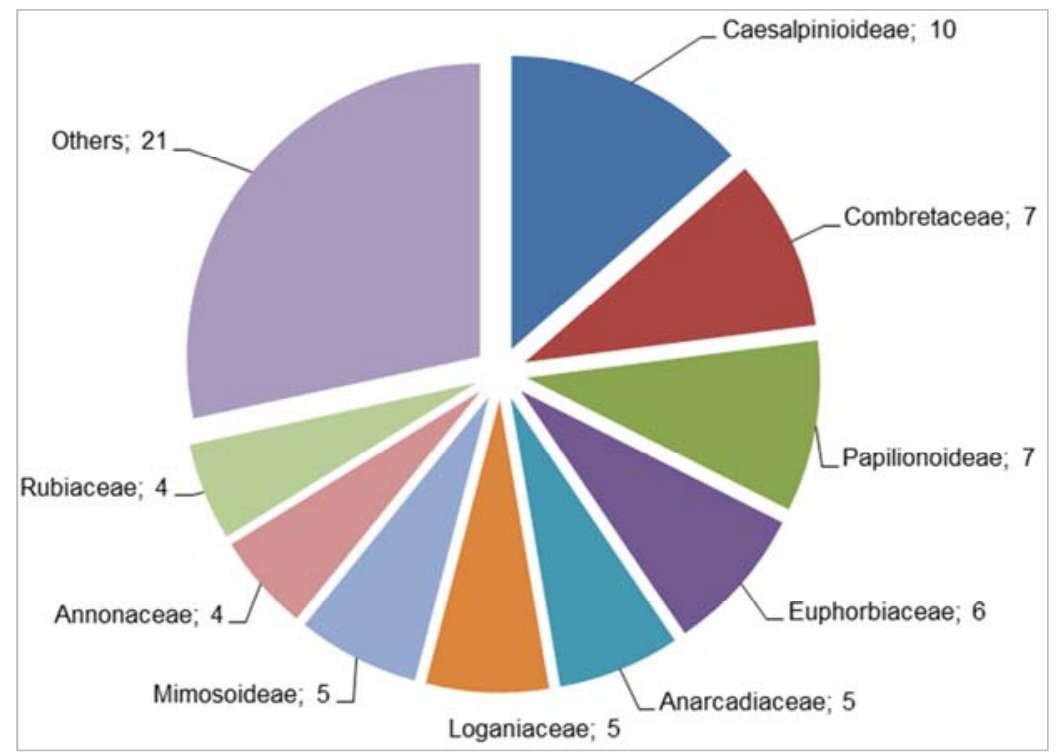

Figure 1. Distribution of 74 identified useful plants by families.

\subsection{The Relative Importance of Tree Species}

As shown in Table 2 and Appendix 1, trees and shrubs recorded were found to have at least one use $(5.6 \%$ of the total possible uses) to six uses (33.3\%). For example, Phyllanthus engleri Pax had only one use (fuel) while Brachystegia spiciformis had six uses (fuel, fodder, timber, ropes, making traditional beehive and traditional storage structures). Records of high score values suggest species are versatile, hence their importance to the community livelihood. Albizia harveyi, Pericorpsis angolensis, Pseudolachnostylis maprouneiformis, and Swartizia madagascariensis were ranked the second with five uses (27\%) each. Tree species such as Ziziphus mocronata, Sytrychnos innocua, Acacia mellifera, Andides mavenosum, Borassu saethiopum and Combretum spidioides had the least one score of uses $(5.6 \%)$. The uses were traditional medicines, fruits and fuelwood, respectively. Analysis of the importance of tree species by major category of uses showed that food plants (46 species: 62.2\%), formed the dominant category. Other important categories were handcraft plants (42 species: $56.8 \%$ ), domestic plants (35 species: $47.3 \%$ ) and spiritual plants (9 species: $12.2 \%$ ). Overall, the results give evidence of the multiple uses of plant species in the Miombo woodland resources (Table 2) and the importance of the resources to the livelihoods of communities in Sikonge as has been reported in other communities $[7,18]$.

Table 2. Summary of species, and their uses.

\begin{tabular}{lll}
\hline Number of species & Number of uses/species & \% of use* \\
\hline 2 & 6 & 33.3 \\
4 & 5 & 27.8 \\
8 & 4 & 22.3 \\
15 & 3 & 16.7 \\
23 & 2 & 11.1 \\
21 & 1 & 5.6 \\
\hline
\end{tabular}

"Percent of uses $=$ number of uses per species/ total number of uses

\section{Food plants}

Findings show that 46 species $(62.2 \%)$ provided food related products. In the study area, the most represented families of food plants were Combretacea and Loganiaceae (represented by six species each), followed by Papilionoideae, Euphorbiaceae and Caesalpinioideae (5 species each), and Annonaceae and Verbenacea (3 species each). Among the categories of uses, medicinal plants and fruits were ranked first and third, respectively. Within this category, 32 species (43.2\%) were used for medicinal purposes with the major parts of extraction being roots, leaves and barks. Twenty species $(27 \%)$ were used as fruits (Table 1 and Appendix 1). Most of these fruits were harvested during the dry season and consumed while fresh. Not only are wild fruits important supplementary source of food (including vitamins and minerals) but also constitute the main source of food during hunger and therefore regarded as safety net.

Further, results show that seven fruit species were used for medicinal purposes implying that fruit consumption could be functional food: ie consumed as food and used as treatment to cure certain diseases. Generally, plants are significant sources of medicines for treatment of various human diseases [37]. The importance of traditional medicines from Miombo woodlands in particular is well documented [38,39]. Indeed, the inefficiency of medical system and expenses associated with modern medicines make the reliance of traditional medicinal plants inevitable. Consequently woodland resources have significant contribution to primary health care services [40]. A report on Agroforestry and achievement of the Millennium Development Goals estimated that $80 \%$ of the rural dwellers in Sub-Saharan Africa depend on medicinal plants for most of their health needs [41]. Fruit sale was also reported as one of the strategies for income generation particularly among women and children. However, fruit potential from Miombo for human consumption has been 
shown to be as low as $10 \%$ because of poor marketing system and rudimentary processing technologies [42]. Marketing interventions of fruits harvested from the Miombo woodlands would significantly improve the income from fruit sale.

Handcraft plants

About 42 species (56.8\%) were used for handcraft purposes. The most represented families were Caesalpinioideae (10 species), followed by Papilionoideae (7 species) and Mimisoideae (5 species) (Table 1 and Appendix 1). Trees in these categories produce hard wood often used for construction of house, roofs, fences and huts. Poles ranked the first with 22 species $(29.7 \%)$ in this category, but the second in all categories of uses. Indeed, most houses in the study area were constructed using poles and plastered with mud. Nine tree species $(12.2 \%)$ were used for making domestic utensils such as mortar and pestle, wooden spoons and grinding pans while six species $(8.1 \%)$ were used for making handles for hoes and axes and traditional sandals. In addition, eight tree species $(10.8 \%)$ were used for timber.

The most common species in the order of importance were Pterocarpus angolensis, Brachystegia spiciformis and Afzelia quenzensis. Another group of eight tree species (10.8\%) was used for making ropes, $6.8 \%$ for construction of traditional beehives (bark and log beehive only made from Pterocarpus angolensis), and $2.7 \%$ for making traditional storage structures for grains locally known as "Vihenge" (Table 1). Of note, the Miombo woodland has a number of species used for wood carvings or furniture [43]. In the study area, Dalbergia melanoxylon belonging to Papilionoideae family was used for carvings. Wood carvings are a prominent activity in the area representing a source of income and employment as in other communities [44, 45, 46]. However, it is worth noting that majority of uses under this category involve destructive harvesting/use such as use of stem/branches and tree debarking, all of which have negative ecological implications. Indeed, selective harvesting for timber, pole and construction of traditional beehives has been singled out as one of the main causes of forest degradation and deforestation [47].

Domestic plants

Thirty-five species (46\%) were within the domestic category of use belonging to 15 families. The most represented families was Caesalpinioideae (6 species), Euphorbiaceae (5 species) and Combretatceae (4 species). A total of 32 species (43.2\%) including Brachystegia spiciformis Benth, Julbernardia globiflora (Benth.) Troupin and Albizia harveyi E. Fourn were used as fuelwood (Table 1 and Appendix 1). Fuelwood was among the first ranked products derived from the Miombo woodlands. These trees have desirable properties notably hot flame, less smoke and/or burning for long time. As in the case of handcraft, use of domestic plants especially fuelwood, involved removal of stem or branches which is destructive to the forest. Although most of the rural communities are known to collect dry fuel wood $[48,49]$, in the study area, community uses green wood for curing tobacco and charcoal making largely for commercial activities, and that results in energy consumption levels that far exceed the normal domestic needs.

Green product harvesting (mainly green cut wood) coupled with conversion of Miombo woodlands to farm lands raised serious environmental concern during focus group discussions. While these activities may represent a significant contribution to livelihood of local communities, the impact on plant diversity, woodland structure and conservation of the Miombo ecosystem is consequential. Such practices are known to be the key drivers of deforestation and forest degradation [18, 47]. These two effects have negative consequences on species diversity and eroding the genetic base of tree species including those used for products and services necessary for domestic needs. On the other hand, three species $(4.0 \%)$ were used as glue mainly for making traditional storage structures and beehives. Lastly, two other tree species (2.7\%) namely Comiphora africana and Comiphora mosambiensis both belonging to Burseraceae were used for live fences at homestead or animal cages.

\section{Spiritual plants}

Spiritual plants including 9 species $(12.2 \%)$ were found to be used for worshiping and ritual activities. The most represented family was Anarcadiaceae with three species, followed by Combretaceae ( 2 species) and five families each represented by one species (Table 1 and Appendix 1). Five species $(6.8 \%)$ were used for worshiping and ritual activities including Combretum molle, Pterocarpus angolensis, Sterculia mhosya, Lannea humilis, and Strychnos pungens. There were four mentions of tree species (5.4\%) for protection against witchcraft. The four trees were Gardenia ternifolia, Cassipourea mollis, Lannea schimperi and Schrebera trichoclada. In general, the Wanyamwezi who are the predominant ethnic group in the study area, attach significant importance to specific trees and even blocks of woodlands for spiritual purposes [14]. Such practices contribute to in situ conservation although spiritual function is the main goal rather than biodiversity conservation per se $[14,50]$. However, the influence of systems of rules, taboos and sanctions for the reckless use of biological resources is rather limited due to weakening of traditional institutions. Nevertheless, cultural and traditional approaches are relevant since they cover broad range of communities.

\section{Miscellaneous/other uses}

Other plants were found to be used for animal grazing and poisoning. This category represented by 10 species $(13.5 \%)$. Of these, nine tree species (12.2\%) were mentioned as important woody plants for pastoral use (Table 1 and Appendix 1). During focus group discussions, it was noted that very few participants had knowledge on feed resources as most of them were predominantly crop producers rather than livestock keepers. Nonetheless studies have documented that the Miombo woodlands provide important feed resources for grazing both for wild and domesticated animals [51, 52]. One species Lannea schimperi belonging to the Anarcadiaceae family was used for poisoning during hunting wild animals. Although this practice is currently illegal, the property of this plant species is worth noting. 


\subsection{Resource Abundance and Availability of Useful Species in Local Miombo Woodlands}

\subsubsection{Species Diversity}

From the forest inventory survey, it was possible to record the presence and distribution of woody plants of ethnobotanical interest of the surrounding the studied communities along the gradient of use. This information is prerequisite for setting up conservation priorities and for planning conservation actions. Results show that of the 6.24 ha surveyed, a total of 435 woody plants belonging to 23 families with 50.4 species ha ${ }^{-1}$ were found in IFR, 367 woody plants belonging to 24 families with 46.4 species ha $^{-1}$ were found in TFZ and 482.5 woody plants belonging to 21 families with mean diversity of 91.2 species ha $^{-1}$ were found in FNS (Table 3). The dominant families in IFR were
Caesalpinioideae, Combretaceae and Papilionoideae, while in TZF were Caesalpinioideae, Combretaceae and Euphorbiaceae and in the FNS were Papilionoideae, Euphorbiaceae and Caesalpinioideae were dominant families.

The higher wood plants density and species diversity in FNS site, suggest that there was over utilization of plant species in the area. Such utilisation might have created space for light penetration or even promoted recruitment resulting in increased abundance and species richness. Previous studies have reported higher density and species diversity near settlement due to overutilization, and that species diversity varies with distance from settlements towards forests [18, 53]. This observation is also consistent with the intermediate disturbance hypothesis in which disturbances are believed to create gaps that favour plant species diversity [54, 55].

Table 3. Density (stems $\left.h a^{-1}\right)$; Basal Area, BA $\left(m^{2} h a^{-1}\right)$, Volume, $V\left(m^{3} h a^{-1}\right)$ and Species Richness (Species ha' $)$, Shannon Weiner Index (H') and family of the surveyed forests.

\begin{tabular}{|c|c|c|c|c|c|c|}
\hline Category & Stems ha ${ }^{-1}$ & BA m ${ }^{2} h a^{-1}$ & $V\left(m^{3} h^{-1}\right)$ & $\mathbf{H}^{\prime}$ & Species ha $^{-1}$ & Family \\
\hline IFR & $696 \pm 48$ & $12.77 \pm 0.8$ & $96.84 \pm 6.4$ & 2.638 & 50.4 & 23 \\
\hline TFZ & $587.2 \pm 53$ & $10.53 \pm 0.8$ & $80.18 \pm 6.6$ & 2.564 & 46.4 & 24 \\
\hline FNS & $1544 \pm 206$ & $8.08 \pm 0.8$ & $41.5 \pm 5.2$ & 2.673 & 91.2 & 21 \\
\hline
\end{tabular}

\subsubsection{Woodland Structure}

The sites in FNS had a higher stem density ha ${ }^{-1}$ compared to other forest zones. Much of this difference was due to the greater density of the trees with diameter less than $10 \mathrm{~cm}$ found in the FNS signifying higher level of harvesting of wood resources (Table 3). Both basal area and volume were higher in IFR. Nearly $72 \%$ of the total basal area and volume contributed by trees with diameter greater than $20 \mathrm{~cm}$. Basal area and volume were comparable for IFR and TFZ but lower values were recorded for FNS. This observation suggests that there was no immediate threat to the forest reserve.

The higher values of density, low value of basal area and volume recorded in FNS areas compared with those of other forest zones are possibly due to overexploitation of certain species under handcraft and domestic uses including Brachystegia spiciformis, Pterocarpus angolensis and Julbernardia globiflora which are characteristically suitable for producing fuelwood, charcoal, curing tobacco and construction of handles and other utensils (see Table 1). This also suggests that the impact of utilization on woodland structure tends to decrease with distance from the settlement area as observed in previous studies $[18,53]$.

\section{Conclusions and Recommendations}

This study has provided evidence that woodland resources provide significant support to the livelihoods of rural communities as they are extensively used for household consumption and life supporting activities. In particular, the study has shown that the benefits of Miombo woodland are diverse ranging from handcraft, fruits, medicinal value, fuelwood, fences, beehives and storage structures for grains. These benefits are derived from various tree species that differ in their relative importance as shown by scores assigned to each species. Nevertheless, most tree species were assigned multiples uses suggesting reduced chances of severe impact of utilisation of few individual species. Evidence also suggests that local people derive more Nontimber Forest Products (NTFP) compared to Timber Forest Products (TFP).

The increase in use of suitable species for charcoal production, building materials and tobacco curing, in order to get a supplementary income, have exerted pressure on Miombo woodlands. While this extractive activity may represent a significant contribution to poverty alleviation, consequences on plant diversity, woodland structure and conservation of the Miombo ecosystem are unfavourable. Accordingly, the results of this study have shown that species diversity and woodlands structure varied with distance from the settlement, suggesting that utilization have major impact to Miombo ecosystem.

Since harvesting of NTFP has less severe impact compared with timber forest products, it is therefore recommended that NTFP from Miombo woodlands be promoted to exploit their full potential. The promotion through improving production (such as domestication), quality control and marketing of NTFP may help to improve community livelihood and promote positive attitude towards environmental conservation. Although most ethno-botanical uses recorded in this study appeared to be sustainable and could be continued and promoted in order to contribute to the poverty alleviation of local people, more efforts are needed to conserve the ecosystem. Conversion of Miombo woodlands to short-duration crop lands and harvesting wood for curing tobacco are matters that need Government attention if these woodland resources are to be sustained. 


\section{Appendix}

Appendix 1. Uses of trees and shrubs in communities surrounding Ugunda Forest Reserve, Sikonge Tanzania.

\begin{tabular}{|c|c|c|c|c|c|c|c|c|c|c|c|c|c|c|c|c|c|c|c|c|}
\hline Species & $\mathbf{F e}$ & M & $\mathbf{P}$ & Fu & Ut & Fo & $\mathbf{T i}$ & $\mathbf{R}$ & Po & На & $\mathbf{W}$ & $\mathrm{Be}$ & $\mathbf{T p}$ & Gu & $\mathbf{B a}$ & Fc & $\mathbf{C u}$ & $\mathbf{P i}$ & $\mathbf{T}$ & $\begin{array}{l}\% \text { of } \\
\text { uses }\end{array}$ \\
\hline Brachystegia spiciformis Benth. & $\mathrm{X}$ & & & & & $\mathrm{X}$ & $\mathrm{X}$ & $\mathrm{X}$ & & & & $\mathrm{X}$ & & & $\mathrm{X}$ & & & & 6 & 33.3 \\
\hline Julbernardia globiflora (Benth.) Troupin & $\mathrm{X}$ & & & & & $\mathrm{X}$ & $\mathrm{X}$ & $\mathrm{X}$ & & & & $\mathrm{X}$ & & & $\mathrm{X}$ & & & & 6 & 33.3 \\
\hline Albizia harveyi E. Fourn. & $\mathrm{X}$ & $\mathrm{X}$ & $\mathrm{X}$ & & $\mathrm{X}$ & & & & & & & $\mathrm{X}$ & & & & & & & 5 & 27.8 \\
\hline Pericopsis angolensis (Baker) Meeuwen & $\mathrm{X}$ & $\mathrm{X}$ & $\mathrm{X}$ & & $\mathrm{X}$ & & & & $\mathrm{X}$ & & & & & & & & & & 5 & 27.8 \\
\hline Pseudolachnostylis maprouneifoliaPax & $\mathrm{X}$ & $\mathrm{X}$ & $\mathrm{X}$ & $\mathrm{X}$ & & & & & $\mathrm{X}$ & & & & & & & & & & 5 & 27.8 \\
\hline Swartzia madagascariensis Desv. & $\mathrm{X}$ & $\mathrm{X}$ & $\mathrm{X}$ & & $\mathrm{X}$ & & $\mathrm{X}$ & & & & & & & & & & & & 5 & 27.8 \\
\hline Annona senegalensis Pers. & & $\mathrm{X}$ & & $\mathrm{X}$ & & $\mathrm{X}$ & & & & $\mathrm{X}$ & & & & & & & & & 4 & 22.2 \\
\hline Combretum collinum Fresen. & $\mathrm{X}$ & $\mathrm{X}$ & $\mathrm{X}$ & & & & & & $\mathrm{X}$ & & & & & & & & & & 4 & 22.2 \\
\hline Combretum zeyheri Sond. & & $\mathrm{X}$ & $\mathrm{X}$ & $\mathrm{X}$ & & & & & & & & & & $\mathrm{X}$ & & & & & 4 & 22.2 \\
\hline Lannea humilis (Oliv.) Engl. & & & & & $\mathrm{X}$ & & $\mathrm{X}$ & $\mathrm{X}$ & & & $\mathrm{X}$ & & & & & & & & 4 & 22.2 \\
\hline Pterocarpus angolensis DC. & & $\mathrm{X}$ & & & & & $\mathrm{X}$ & & & & $\mathrm{X}$ & $\mathrm{X}$ & & & & & & & 4 & 22.2 \\
\hline Pterocarpus tinctorius Welw. & $\mathrm{X}$ & $\mathrm{X}$ & $\mathrm{X}$ & & & & $\mathrm{X}$ & & & & & & & & & & & & 4 & 22.2 \\
\hline Strychnos potatorius L.f. & & $\mathrm{X}$ & $\mathrm{X}$ & & & & & $\mathrm{X}$ & $\mathrm{X}$ & & & & & & & & & & 4 & 22.2 \\
\hline Terminalia sericea Burch. ex DC. & $\mathrm{X}$ & $\mathrm{X}$ & $\mathrm{X}$ & & & & & & & & 1 & & & & & & & & 4 & 22.2 \\
\hline Afzelia quanzensis Welw. & $\mathrm{X}$ & $\mathrm{X}$ & & & & & $\mathrm{X}$ & & & & & & & & & & & & 3 & 16.7 \\
\hline Brachystegia boehmii Taub. & $\mathrm{X}$ & & & & & & & $\mathrm{X}$ & & & & $\mathrm{X}$ & & & & & & & 3 & 16.7 \\
\hline Cassipourea mollis (R.E.Fr.) Alston & & $\mathrm{X}$ & $\mathrm{X}$ & & & & & & & & & & $\mathrm{X}$ & & & & & & 3 & 16.7 \\
\hline $\begin{array}{l}\text { Cambretuma denogonium Steud. Ex A. } \\
\text { Rich. }\end{array}$ & $\mathrm{X}$ & $\mathrm{X}$ & & & & & & & & & & & & $\mathrm{X}$ & & & & & 3 & 16.7 \\
\hline
\end{tabular}

Appendix 1. Cont....

\begin{tabular}{|c|c|c|c|c|c|c|c|c|c|c|c|c|c|c|c|c|c|c|c|c|}
\hline Species & $\mathbf{F e}$ & M & $\mathbf{P}$ & Fu & $\mathbf{U t}$ & Fo & $\mathbf{T i}$ & $\mathbf{R}$ & Po & $\mathrm{Ha}$ & $\mathbf{W}$ & $\mathrm{Be}$ & Tp & Gu & $\mathbf{B a}$ & Fe & $\mathbf{C u}$ & $\mathbf{P i}$ & $T$ & $\mathbf{U v}$ \\
\hline Crossopteryx febrifuga (Afzel. ex G.Don) & $\mathrm{X}$ & $\mathrm{X}$ & $\mathrm{X}$ & & & & & & & & & & & & & & & & 3 & 16.7 \\
\hline Diospyros mespiliformis Hochst. ex.A.DC. & $\mathrm{X}$ & & & $\mathrm{X}$ & & & & & & & & & & $\mathrm{X}$ & & & & & 3 & 16.7 \\
\hline Erythrophleum africanum (Benth.) Harms & $\mathrm{X}$ & & $\mathrm{X}$ & & & & & & $\mathrm{X}$ & & & & & & & & & & 3 & 16.7 \\
\hline Friesodielsia obovata (Benth.) Verdc. & & & & $\mathrm{X}$ & & $\mathrm{X}$ & & & $\mathrm{X}$ & & & & & & & & & & 3 & 16.7 \\
\hline $\begin{array}{l}\text { Hexalobus monopetalus (A.Rich.) } \\
\text { Engl.\&Diels }\end{array}$ & $\mathrm{X}$ & & & $\mathrm{X}$ & & $\mathrm{X}$ & & & & & & & & & & & & & 3 & 16.7 \\
\hline Lannea schimperi (Hochst.exA.Rich) Engl. & & & & & & & & $\mathrm{X}$ & & & & & $\mathrm{x}$ & & & & & $\mathrm{X}$ & 3 & 16.7 \\
\hline Markhamia obtusifolia (Baker) Sprague & $\mathrm{X}$ & & & & $\mathrm{x}$ & & & & & $\mathrm{X}$ & & & & & & & & & 3 & 16.7 \\
\hline Oldifieldia dactylophylla J. Leonard. & $\mathrm{X}$ & $\mathrm{X}$ & $\mathrm{X}$ & & & & & & & & & & & & & & & & 3 & 16.7 \\
\hline Parinaricuratellifolia Planch.exBenth. & $\mathrm{X}$ & & & $\mathrm{X}$ & & $\mathrm{X}$ & & & & & & & & & & & & & 3 & 16.7 \\
\hline Tamarindus indica L. & & $\mathrm{X}$ & & $\mathrm{X}$ & & $\mathrm{X}$ & & & & & & & & & & & & & 3 & 16.7 \\
\hline Vitex mombassae Vatker & $\mathrm{X}$ & $\mathrm{X}$ & & $\mathrm{X}$ & & & & & & & & & & & & & & & 3 & 16.7 \\
\hline Albizia antunesiana Harms & & & $\mathrm{X}$ & & & & $\mathrm{X}$ & & & & & & & & & & & & 2 & 11.1 \\
\hline Albizia petersiana (Bolle) Oliv. & $\mathrm{X}$ & & & & $\mathrm{X}$ & & & & & & & & & & & & & & 2 & 11.1 \\
\hline Balanite saegyptiaca (L.) Del. & & $\mathrm{X}$ & & & & & & & & $\mathrm{X}$ & & & & & & & & & 2 & 11.1 \\
\hline Brachystegia glaberrima R.E.Fr. & & & & & $\mathrm{X}$ & & & $\mathrm{X}$ & & & & & & & & & & & 2 & 11.1 \\
\hline Combretum molle R.Br. ex G.Don & & $\mathrm{X}$ & & & & & & & & & $\mathrm{X}$ & & & & & & & & 2 & 11.1 \\
\hline Commiphora Africana (A.Rich.) Engl. & & & & & & & & $\mathrm{X}$ & & & & & & & & $\mathrm{X}$ & & & 2 & 11.1 \\
\hline Diospyros fischeri(Gurke) & $\mathrm{X}$ & $\mathrm{X}$ & & & & & & & & & & & & & & & & & 2 & 11.1 \\
\hline $\begin{array}{l}\text { Diplorhynchus condylocarpon (Mull.Arg.) } \\
\text { Pichon }\end{array}$ & $\mathrm{X}$ & & & & & & & & & $\mathrm{X}$ & & & & & & & & & 2 & 11.1 \\
\hline Flacourtia indica (Burn.f.) Merr. & $\mathrm{X}$ & & & $\mathrm{X}$ & & & & & & & & & & & & & & & 2 & 11.1 \\
\hline Lonchocarpus bussei Harms & $\mathrm{X}$ & & & & & & & & & $\mathrm{X}$ & & & & & & & & & 2 & 11.1 \\
\hline Mangifera indica L. & & $\mathrm{X}$ & & $\mathrm{X}$ & & & & & & & & & & & & & & & 2 & 11.1 \\
\hline Manilkara mochisia (Baker) Dubard & $\mathrm{X}$ & & & $\mathrm{X}$ & & & & & & & & & & & & & & & 2 & 11.1 \\
\hline Ochnalongipes Baker & & $\mathrm{X}$ & & & & & & & $\mathrm{X}$ & & & & & & & & & & 2 & 11.1 \\
\hline Ozoroa insignis Delile & & $\mathrm{X}$ & & & & & & & & $\mathrm{X}$ & & & & & & & & & 2 & 11.1 \\
\hline Schrebera trichoclada Welw. & & $\mathrm{X}$ & & & & & & & & & & & $\mathrm{x}$ & & & & & & 2 & 11.1 \\
\hline Sclerocarya birrea (A. Rich.) Hochst. & & & & & $\mathrm{X}$ & & & & & & & & & & & & & & 2 & 11.1 \\
\hline
\end{tabular}


Appendix 1. Cont....

\begin{tabular}{|c|c|c|c|c|c|c|c|c|c|c|c|c|c|c|c|c|c|c|c|c|}
\hline Species & $\mathbf{F e}$ & M & $\mathbf{P}$ & $\mathbf{F u}$ & Ut & Fo & $\mathbf{T i}$ & $\mathbf{R}$ & Po & $\mathrm{Ha}$ & $\mathbf{W}$ & $\mathrm{Be}$ & $\mathbf{T p}$ & Gu & $\mathbf{B a}$ & Fc & $\mathbf{C u}$ & $\mathbf{P i}$ & $\mathbf{T}$ & $\mathbf{U v}$ \\
\hline Strychnos pungens Soler. & & & $\mathrm{X}$ & $\mathrm{X}$ & & & & & & & $\mathrm{X}$ & & & & & & & & 2 & 11.1 \\
\hline Strychnos spinosa Lam. & & & $\mathrm{X}$ & $\mathrm{X}$ & & & & & & & & & & & & & & & 2 & 11.1 \\
\hline $\begin{array}{l}\text { Strychonos cocculoides } \\
\text { Baker }\end{array}$ & & $X$ & & $X$ & & & & & & & & & & & & & & & 2 & 11.1 \\
\hline Vitex doniana Sweet & $\mathrm{X}$ & & & $\mathrm{X}$ & & & & & & & & & & & & & & & 2 & 11.1 \\
\hline $\begin{array}{l}\text { Xeroderris stuhlmannii } \\
\text { (Taub.) Mendonca \& E.C. } \\
\text { Sousa }\end{array}$ & & $\mathrm{X}$ & & & $\mathrm{X}$ & & & & & & & & & & & & & & 2 & 11.1 \\
\hline Ximenia caffraSond. & $\mathrm{X}$ & & & $\mathrm{X}$ & & & & & & & & & & & & & & & 2 & 11.1 \\
\hline $\begin{array}{l}\text { Xylopia antunesii Engl. \& } \\
\text { Diels }\end{array}$ & & & $\mathrm{X}$ & & & $\mathrm{X}$ & & & & & & & & & & & & & 2 & 11.1 \\
\hline $\begin{array}{l}\text { Acacia mellifera (Vahl) } \\
\text { Benth. }\end{array}$ & $\mathrm{X}$ & & & & & & & & & & & & & & & & & & 1 & 5.6 \\
\hline $\begin{array}{l}\text { AntidesmavenosumE. } \\
\text { Mey.exTul. }\end{array}$ & & & & $\mathrm{X}$ & & & & & & & & & & & & & & & 1 & 5.6 \\
\hline Borassus aethiopum Mart. & & & & $\mathrm{X}$ & & & & & & & & & & & & & & & 1 & 5.6 \\
\hline Burkea Africana Hook. & & & $\mathrm{X}$ & & & & & & & & & & & & & & & & 1 & 5.6 \\
\hline Cassia abbreviate Oliv. & & $\mathrm{X}$ & & & & & & & & & & & & & & & & & 1 & 5.6 \\
\hline $\begin{array}{l}\text { Combretum psidioides } \\
\text { Welw. }\end{array}$ & $\mathrm{X}$ & & & & & & & & & & & & & & & & & & 1 & 5.6 \\
\hline $\begin{array}{l}\text { Combretum obovatum F. } \\
\text { Hoffm. }\end{array}$ & & & & & & $\mathrm{X}$ & & & & & & & & & & & & & 1 & 5.6 \\
\hline $\begin{array}{l}\text { Commiphora } \\
\text { mossambicensis (Oliv.) } \\
\text { Engl. }\end{array}$ & & & & & & & & & & & & & & & & $\mathrm{X}$ & & & 1 & 5.6 \\
\hline $\begin{array}{l}\text { Dalbergiamelanoxylon } \\
\text { Guill. et Perrott. }\end{array}$ & & & & & & & & & & & & & & & & & $\mathrm{X}$ & & 1 & 5.6 \\
\hline Dalbergia nitidula Baker & & & $\mathrm{X}$ & & & & & & & & & & & & & & & & 1 & 5.6 \\
\hline $\begin{array}{l}\text { Dichrostachys cinereaWight } \\
\text { et Arn. }\end{array}$ & & & $\mathrm{X}$ & & & & & & & & & & & & & & & & 1 & 5.6 \\
\hline $\begin{array}{l}\text { Erythrina abyssinica Lam. } \\
\text { ex DC }\end{array}$ & & $\mathrm{X}$ & & & & & & & & & & & & & & & & & 1 & 5.6 \\
\hline Euphorbia grantii Oliv. & & & $\mathrm{X}$ & & & & & & & & & & & & & & & & 1 & 5.6 \\
\hline $\begin{array}{l}\text { Fadogia } \\
\text { cienkowskiSchweinf.var }\end{array}$ & & $\mathrm{X}$ & & & & & & & & & & & & & & & & & 1 & 5.6 \\
\hline $\begin{array}{l}\text { Gardenia ternifolia } \\
\text { Schumach. \&Thonn. }\end{array}$ & & & & & & & & & & & & & $\mathrm{X}$ & & & & & & 1 & 5.6 \\
\hline $\begin{array}{l}\text { Margaritaria discoidea } \\
\text { (Baill.) G.L. Webster }\end{array}$ & $\mathrm{X}$ & & & & & & & & & & & & & & & & & & 1 & 5.6 \\
\hline $\begin{array}{l}\text { Ochna schweinfurthiana F. } \\
\text { Hoffm }\end{array}$ & & $\mathrm{X}$ & & & & & & & & & & & & & & & & & 1 & 5.6 \\
\hline Phyllanthus engleri Pax & $\mathrm{X}$ & & & & & & & & & & & & & & & & & & 1 & 5.6 \\
\hline Sterculia mhosya Engl. & & & & & & & & & & & $\mathrm{x}$ & & & & & & & & 1 & 5.6 \\
\hline Strychnos innocua Delile & & & & $\mathrm{x}$ & & & & & & & & & & & & & & & 1 & 5.6 \\
\hline $\begin{array}{l}\text { Vangueriopsis lanciflora } \\
\text { (Hiern) Robyns }\end{array}$ & & & $\mathrm{X}$ & & & & & & & & & & & & & & & & 1 & 5.6 \\
\hline Ziziphus mucronataWilld. & & $\mathrm{X}$ & & & & & & & & & & & & & & & & & 1 & 5.6 \\
\hline Total & 32 & 32 & 22 & 20 & 9 & 9 & 8 & 8 & 7 & 6 & 6 & 5 & 4 & 3 & 2 & 2 & 1 & 1 & & \\
\hline$\%$ & 43.2 & 43.2 & 29.7 & 27 & 12.2 & 12.2 & 10.8 & 10.8 & 9.5 & 8.1 & 8.1 & 6.8 & 5.4 & 4.1 & 2.7 & 2.7 & 1.4 & 1.4 & & \\
\hline
\end{tabular}

Keys: Fu- Fruit, P-Pole, Fe-Fuelwood, Ut-Wood Utensils, M-Traditional Medicine, Pi-Poison, Be-Traditional Beehive, Ba-Traditional Storage Structures, RRopes, Ha-Handles, Fc-Fences, Cu-Carvings, Ti-Timber, Tp-Traditional Protection, Po-Small Poles, W-Worshipping, Fo-Fodder, T-Total number of uses

\section{References}

[1] Frost, P. G. H., Timberlake, J., \& Chidumayo, E. (2003). Miombo-mopane woodlands and grasslands. In: Mittermeier R, Goettsch Mittermeier C, Robles Gil P, Fonseca G, Brooks T, Pilgrim J., \& Konstant W (editors). Wilderness: earth's last wild places. Chicago, IL: University of Chicago Press. p. 183204.
[2] Chidumayo, E. N. \& Gumbo, D. J. (2010). The dry forests and woodlands of Africa. Managing for products and services. London: Earthscan.

[3] Dewees, P., Campbell, B., Katerere, Y., Sitoe, A., Cunningham, A. B., Angelsen, A., \& Wunder, S. (2011). Managing the miombo woodlands of southern Africa: policies, incentives, and options for the rural poor. Washington, DC: World Bank Program on forests (PROFOR). [Plus annexes:http://www.profor/sites/profor.info/files/Miombo Annexes_Nov11.pdf 
[4] Borota, J. (1991). Tropical forests: Some Africa and Asian case studies of composition and structure. In: developments in Agricultural and Managed-Force. Ecology, 22, 166 - 167.

[5] Rodgers, W. A. (1996). The Miombo woodlands. In: McClanahan, T. R. and Young, T. P. (EDS.) East Africa ecosystems and their conservation. Oxford University Press, Oxford. pp. 299-325.

[6] Campbell, B. M., Angelsen, A., Cunningham, A., Katerere, Y., Sitoe. A., \& Wunder, S. (2007): Miombo WoodlandsOpportunities and Barriers to Sustainable Forest Management. Bogor: CIFOR.

[7] Njana, M. A., Kajembe, G. C., \& Malimbwi, R. E. (2013) Are Miombo woodlands vital to livelihoods of rural households? Evidence from Urumwa and surrounding communities, Tabora, Tanzania. Forests, Trees and Livelihoods 22(2): 124140. [DOI: 10.1080/14728028.2013.803774]. site visited on 05/06/2016.

[8] Shirima, D. D. Totland, Ø. Munishi, P. K., \& Moe, S. R. (2015). Relationships between tree species richness, evenness and aboveground carbon storage in montane forests and miombo woodlands of Tanzania. Basic and Applied Ecology 16(3): 239-249.

[9] Desanker, P. V. Frost, P. G. H. Frost, C. O. Justice, C. O., \& Scholes, R. J. (eds.). (1997). The Miombo network: Frameworks for a terrestrial transect study of land use and land-cover change in the Miombo ecosystems of Central Africa, IGBP Report 41, The International Geosphere Biosphere Programme (IGBP), Stockholm, Sweden. 109 p.

[10] Koller, R., \& Samimi, C. (2011). Deforestation in the Miombo woodlands: A pixel-based Semi - automated change detection method. International journal of remote sensing 32(22): 7631 7649 .

[11] MNRT (2006). Conservation and Management of the Eastern Arc Mountain Forests Project: Forest Area Baseline for the Eastern Arc Mountains. 47 pp.

[12] Luoga, E. J. Witkowski, E. T. F., \& Balkwill, K. (2000). Subsistence use of wood products and shifting cultivation within a miombo woodland of eastern Tanzania, with some notes on commercial uses. South African Journal of Botany 66 (1): $72-85$.

[13] Lupala, Z. J. Lusambo, L. P., \& Ngaga, Y. M. (2014). Management, growth, and carbon storage in Miombo woodlands of Tanzania. International Journal of Forestry Research,

[14] Mgumia, F. H., \& Oba, G. (2003). Potential role of sacred groves in biodiversity conservation in Tanzania. Environmental conservation 30(3):259 - 265.

[15] Saidi, T. A., \& Tshipala-Ramatshimbila, T. V. (2006). Ecology and management of a remnant Brachystegiaspiciformis (Miombo) woodland in North Eastern Soutpansberg, Limpopo povince. South African Geographical Journal 88(2): 205-212.

[16] Schrotter, C. Duguma, L. Snook, L. Loo, J. Alves, T. Sousa, C., \& Gratzer, G. (2016). Destructive harvesting of wild honey in Miombo woodlands affects keystone elements in the ecosystem. [Abstract] presented at: Tropentag 2016: Solidarity in a competing world - fair use of resources. Vienna (Austria) Sep 18-21. 1 p.

[17] Luoga, E. J. (2000). The effect of human disturbances on diversity and dynamics of eastern Tanzania Miombo arborescent species. A thesis submitted to the Faculty of Science, University of the Witwaterrand, Johannesburg in fulfilment of the requirements for the degree of Doctor of Philosophy.

[18] Bruschi, P. Mancini, M. Mattioli, E. Morganti, M., \& Maria Adele Signorini, M. A. (2014). Traditional uses of plants in a rural community of Mozambique and possible links with Miombo degradation and harvesting sustainability. Journal of Ethnobiology and Ethnomedicine 10:59 [http://www.ethnobiomed.com/content/10/1/59]. Site visited on $07 / 01 / 2017$.

[19] Stanley, D. Voeks, R., \& Short, L. (2012): Is non-timber forest product harvest sustainable in the less developed world? A systematic review of the recent economic and ecological literature. Ethnobiol Cons 6. Available at: [http://ethnobioconservation.com/index.php/ebc/article/view/1 9]

[20] National Land Use Planning Commission - NLUPC, (1999). Nzega District Land Use. Framework Plan. NZega district council. $51 \mathrm{p}$.

[21] Rastogi, A. (1999). Methods in applied ethnobotany: Lessons from the field. International Centre for Integrated Mountain Development, Kathmandu, Nepal. MNR Series, No. 99/1.

[22] McGregor, J. (1994). Woodland pattern and structure in a peasant farming area of Zimbabwe: ecological determinants and present and past use. For Ecol Man 63:97-113

[23] Mbuya, L. P. Msanga, H. P. Ruffo, C. K. Birnie, A., \& Tengnas, B. O. (1994). Useful trees and shrubs for Tanzania. SIDA (Swedish Intern. Develop. Auth.), Nairobi, Kenya, 542 pp.

[24] Martin, G. J. (1995). Ethno-botany. A methods manual. WWF (World Wide Fund for Nature) International. Chapman \& Hall, London. p. 166-167.

[25] Philip, M. S. (1983). Measuring trees and forestry. A textbook written for students in Africa. The division of forestry, University of Dar es Salaam, Tanzania. 338 p.

[26] Malimbwi, R. E. Solberg, B., \& Luoga, E. (1994). Estimation of biomass and volume in miombo woodlands at Kitulangalo Rorest Reserve. Tanzania Journal of Tropical Forest Science 7(2): 230-242.

[27] Kent, M., \& Coker, P. (1992). Vegetation description and analysis. A practical approach. Belhaven Press, London. 363 p.

[28] Kanschik, W., \& Becker, B. (2001). Dry Miombo-ecology of its major plant species and their potential use as bioindicators. Plant ecology 155(2): 139-146.

[29] Stave, J. Oba, G. Nordal, I., \& Stenseth, N. C. (2007). Traditional ecological knowledge of a riverine forest in Turkana, Kenya: implications for research and management. Biodiversity and Conservation 16(5): 1471-1489.

[30] Syampungani, S. Geldenhuys, C. J., \& Chirwa, P. W. (2010). The use of species-stem Curves in sampling the development of the Zambian miombo woodland species in charcoal production and slash-and-burn regrowth stands. Southern Forests 72(2): 83-89. 
[31] Anderson, A. B. (1990). Extraction and forest management by rural inhabitants in the Amazon estuary. In Alternatives to Deforestation: Steps Towards Sustainable Use of the Amazon Rain Forest. Edited by Anderson AB. New York: Columbia University Press. Pp 65-85.

[32] Arnold, J., \& Ruiz-Pérez, M. (2001). Can non-timber forest products match tropical forest conservation and development objectives? Ecol Econ 39:437-447.

[33] Shiva, M. P., \& Verma, S. K. (2002). Approaches to Sustainable Forest Management and Biodiversity Conservation: with Pivotal Role of Non-Timber Forest Products. Dehra Dun: Centre for Minor Forest Products, Valley Offset Printers.

[34] Belcher, B. Ruiz-Pérez, M., \& Achdiawan, R (2005). Global pattern and trends in the use and management of commercial NTFPs: implications for livelihood and conservation. World Dev 33:1435-1452.

[35] Chediack, S. E. (2008). The effect of forest exploitation on structure, diversity, and floristic composition of palmitodominated Atlantic forests at Misiones, Argentina. Rev Biol Trop 56:721-738.

[36] Millington, A., \& Townsend, J. (1989). Biomass Assessment: Woody Biomass in the SADCC Region. London: Earthscan Publications.

[37] Shosan, L. O. Fawibe, O. O. Ajiboye, A. A. Abeegunrin, T. A., \& Agboola, D. A. (2014). Ethnobotanical survey of medicinal plants used in curing some diseases in infants in Abeokuta South Local Government Area of Ogun State, Nigeria. American Journal of Plant Sciences 5(21): 3258.

[38] Kalaba, F. K. Quinn, C. H., \& Dougill, A. J. (2013). Contribution of forest provisioning ecosystem services to rural livelihoods in the Miombo woodlands of Zambia. Population and Environment 35(2): 159-182.

[39] Bundschuh, T. V. Hahn, K., \& Wittig, R. (2016). The medicinal plants of the woodlands in northern Malawi (Karonga district). Flora et VegetatioSudano-Sambesica 14: 38.

[40] Augustino, S. Hall, J. B. Makonda, F. B. S., \& Ishengoma, R. C. (2014). Medicinal plant parts and practices used by communities around the Miombo woodlands of Urumwa, Tanzania. Journal of Medicinal Plant Research 8(15): 599 606.

[41] Garrity, D. P. (2004). Agroforestry and achievement of the Millennium Development Goals. Agroforestry Systems 61: 517.

[42] Abdallah, J. M. (2001). Assessment of the impact of nontimber forest products utilization on sustainable management of Miombo woodlands in Urumwa Forest Reserve, Tabora, Tanzania. A dissertation submitted in partial fulfilment of the requirements for the Degree of Master of Science in Forestry of Sokoine University of Agriculture. 99 p.

[43] Syampungani, S. Chirwa, P. W. Akinnifesi, F. K. Sileshi, G., \& Ajayi, O. C. (2009). The miombo woodlands at the cross roads: Potential threats, sustainable livelihoods, policy gaps and challenges. Natural Resources Forum 33, 150-159

[44] Neba, N. E. (2010). Developing rural tourism as an alternative strategy for poverty alleviation in protected areas: Example of Oku, Cameroon. International NGO Journal 5(2): 050-058.

[45] Mbaiwa, J. E. (2011). Changes on traditional livelihood activities and lifestyles caused by tourism development in the Okavango Delta, Botswana. Tourism Management 32(5): 1050-1060.

[46] Rich, V. (2012). Carving a Life: The Political Economy of Woodcarver Livelihoods in Cabo Delgado, Northern Mozambique (Doctoral dissertation, University of London).

[47] Mangora, M. M. (2012). Shifting cultivation, wood use and deforestation attributes of Tobacco farming in Urambo district, Tanzania. Curr Res J Soc Sci. 4(2):135-140.

[48] Adhikari, B., Di Falco, S., \& Lovett, J. C. (2004). Household characteristics and forest dependency: evidence from common property forest management in Nepal. Ecological economics 48(2): 245-257.

[49] Mamo, G., Sjaastad, E., \&Vedeld, P. (2007). Economic dependence on forest resources: A case from Dendi District, Ethiopia. Forest Policy and Economics, 9(8), 916-927.

[50] Attuaquayefio, D. K., \& Folib, J. N. (2005). An overview of biodiversity conservation in Ghana: challenges and prospects. West African Journal of Applied Ecology 7(1).

[51] Tony, W., \& Homewood, K. (2010). Ecology of African Pastoralist Societies, 162-165.

[52] Kavana, P. Y., \& Kakengi, V. A. M. (2014). Availability of pasture for domestic and wild herbivores in grazing land of Mpanda Tanzania. Livestock Research for Rural Development 26(2).

[53] Jew, E. K. K., Dougill, A. J., Sallu. S. O’Connell, J., \& Benton, T. G. (2016). Miombo woodland under threat: Consequences for tree diversity and carbon storage. Forest Ecology and Management 361: 144 - 153.

[54] Hughes, A. R. Byrnes, J. E., \& Stachowicz J. J. (2007). Reciprocal relationships and potential feedbacks between biodiversity and disturbance. Ecology letters 10: 849-864.

[55] Torras O., \& Saura S. (2008). Effects of silvicultural treatments on forest biodiversity indicators in the Mediterranean. Forest Ecology and Management 255: 33223330 . 